\title{
Aquatic macroinvertebrate biodiversity associated with artificial agricultural drainage ditches
}

\author{
M. J. Hill • R. P. Chadd - N. Morris • \\ J. D. Swaine $\cdot$ P. J. Wood
}

Received: 9 November 2015/Revised: 31 March 2016/Accepted: 1 April 2016/Published online: 16 April 2016

(C) The Author(s) 2016. This article is published with open access at Springerlink.com

\begin{abstract}
Agricultural drainage ditches are ubiquitous features in lowland agricultural landscapes, built primarily to facilitate land drainage, irrigate agricultural crops and alleviate flood risk. Most drainage ditches are considered artificial waterbodies and are not typically included in routine monitoring programmes, and as a result the faunal and floral communities they support are poorly quantified. This paper characterises the aquatic macroinvertebrate diversity (alpha, beta and gamma) of agricultural drainage ditches managed by an internal drainage board in Lincolnshire, UK. The drainage ditches support very diverse macroinvertebrate communities
\end{abstract}

Handling editor: Beat Oertli

Electronic supplementary material The online version of this article (doi:10.1007/s10750-016-2757-z) contains supplementary material, which is available to authorized users.

M. J. Hill · J. D. Swaine · P. J. Wood $(\bowtie)$

Department of Geography, Centre for Hydrological and

Ecosystem Science, Loughborough University,

Loughborough, Leicestershire LE11 3TU, UK

e-mail: P.J.Wood@lboro.ac.uk

R. P. Chadd

Environment Agency of England and Wales, Anglian Region, Northern Area, Waterside House, Waterside

North, Lincoln, Lincolnshire LN2 5HA, UK

N. Morris

Welland and Deepings Internal Drainage Board, Deeping

House, Welland Terrace, Spalding PE11 2TD, UK at both the site (alpha diversity) and landscape scale (gamma diversity) with the main arterial drainage ditches supporting greater numbers of taxa when compared to smaller side ditches. Examination of the between site community heterogeneity (beta diversity) indicated that differences among ditches were high spatially and temporally. The results illustrate that both main arterial and side ditches make a unique contribution to aquatic biodiversity of the agricultural landscape. Given the need to maintain drainage ditches to support agriculture and flood defence measures, we advocate the application of principles from 'reconciliation ecology' to inform the future management and conservation of drainage ditches.

Keywords Drainage channel · Invertebrates · Wetland habitat · Reconciliation ecology · Conservation $\cdot$ Species richness

\section{Introduction}

Land drainage improvements across Europe have historically been followed by the large-scale conversion of lowland wetlands to intensive arable production. This has resulted in a wide range of documented changes and adverse effects upon biological communities across terrestrial, riparian and aquatic landscapes (Buisson et al., 2008; van Eerden et al., 2010). Contemporary European wetlands exist as isolated 
fragments of their former extent, with those that remain largely surrounded by agricultural land (Verdonschot et al., 2011). Wetland habitat loss across Europe is most likely to continue as agricultural intensification, land conversion and water abstraction continue to exert pressure (Maltby \& Acreman, 2011). Frequently, the only remaining aquatic habitat/refuges that exist in agricultural landscapes are ponds (e.g., Sayer et al., 2012) and drainage ditch networks. However, the potential importance of drainage ditch habitats in supporting aquatic biodiversity, the persistence of wetland floral or faunal communities, or species of conservation interest, has been poorly quantified internationally to date (Katano et al., 2003; Maltchik et al., 2011, Leslie et al., 2012; Vaikre et al., 2015).

Ditches are defined as man-made channels created principally for agricultural purposes, which often follow linear field boundaries, turning at right angles and frequently display little relationship with natural landscape topography (Davies et al., 2008a). Drainage ditches created in lowland agricultural regions often occur in dense networks, characterised by larger main ditches (arterial drainage channels-where flow is preferentially conveyed by gravity or by pumping) and smaller side ditches (smaller channels within which water levels can be controlled by the use of weirs and can be isolated from the main arterial channel; Clarke, 2015). Extensive linear networks of drainage ditches extend over an estimated 128,000 km in the UK (Clare $\&$ Edwards, 1983). The primary anthropogenic function of drainage ditches is to convey water to agricultural land, to support crop irrigation during the growing season/dry periods and to divert water away from agriculture and urban infrastructure within towns and villages (flood alleviation) during wetter periods. Agricultural drainage ditches are frequently subject to a range of routine management activities including dredging/in-channel vegetation management and bank vegetation cutting to maintain efficient conveyance of water and reduce flood risk (Clarke, 2015).

For EU water framework directive (WFD) purposes, most drainage ditches are classified as either artificial water bodies (AWB) or as heavily modified water bodies (HMWB) if they follow the course of a pre-existing watercourse (EU, 2000). Given their importance in supporting the irrigation of crops and flood defence, they are managed primarily as agricultural and flooding alleviation infrastructure. As a result, unlike other lentic and lotic surface waterbodies, their ecology may not be required to be monitored on a regular basis, and there is no obligation for them to achieve the WFD requirement of good ecological status (GES). Instead, the alternative target of good ecological potential (GEP) is applied to AWB and HMWB. This designation reflects the anthropogenic requirements placed upon them, the social and economic benefits of the services they provide, and that it may not be practically or economically possible to modify or change the existing configuration (EU, 2000; Environment Agency, 2009).

Agricultural drainage ditches have typically been reported to support lower taxonomic richness compared with other waterbodies (streams, rivers, lakes and ponds), which has been attributed to their close proximity to intensive agricultural activities and the runoff of herbicides, pesticides and fertilisers into them, the latter reducing floral richness with knock-on effects on the fauna (e.g., Williams et al., 2003; Davies et al., 2008b). However, a number of case studies have demonstrated the importance of drainage ditches as reservoirs for aquatic fauna and flora populations (Goulder, 2008; Verdonschot et al., 2011; Whatley et al., 2015). A number of studies have also illustrated that drainage ditches can have significant conservation value, supporting high biodiversity and communities of conservation value, even in intensively cultivated and managed agricultural landscapes (e.g., Foster et al., 1990; Armitage et al., 2003; Williams et al., 2003). Ditches supporting high taxonomic richness typically occur in areas where historic lowland fen occurred and often have continuity with ancient wetlands (Davies et al., 2008b).

This paper aims to highlight the aquatic macroinvertebrate biodiversity and conservation value associated with lowland agricultural drainage ditches (large main ditches and smaller side ditches) over three seasons, and to discuss how principles of reconciliation ecology may provide a sustainable strategy for conserving biodiversity in ditches while supporting their wider societal and anthropogenic functions.

\section{Materials and methods}

Study sites

Deeping Fen $\left(52.746827^{\circ} \mathrm{N}, 0.24762523^{\circ} \mathrm{W}\right)$ is an area of low-lying, intensively cultivated agricultural 
land encircled by the River Glen and River Welland, Lincolnshire, UK. Historically, Deeping Fen was part of 100,000 ha of wild fenland, but as a result of extensive draining for intensive arable agriculture over several centuries, less than 55 ha of natural fenland remain, representing a loss of $99 \%$ (Boyes \& Russell, 1977; Wet Fens Partnership, 2015). An extensive network of drainage ditches, river embankments and water pumping systems operate within the Welland and Deepings Internal Drainage Board area. The drainage ditches are surrounded by intensive arable farming and subject to water level management with water pumped from the ditches during periods of high rainfall into the tidal River Welland to reduce flood risk. During the growing season and periods of low precipitation, water levels in the drainage ditches are raised through a reduction in pumping, the management of weir boards in side channels to reduce the drainage of water and through a series of valves on the River Welland and Greatford Cut that allow water into the system. In effect, the drainage ditche water levels are kept artificially low during the winter and raised during the summer to support agricultural irrigation and provide environmental benefits to support a site of high conservation interest (Cross Drain Site of Special Scientific Interest - Natural England, 2015). This results in highly regulated water levels that are in complete contrast to the pattern displayed in the proximal River Welland.

A total of 12 sites were surveyed in Deeping Fen on three occasions during 2014, corresponding to spring, summer and winter. Two types of drainage ditch sites were selected: (i) 7 sites on two of the longest main arterial drainage ditches-wider $(>5 \mathrm{~m}$ wide) and longer ditches which are connected to a large number of side ditches. The main arterial drainage ditches (North Drove and South Drove Drains) are maintained on an annual basis, with the vegetation on alternate banks cut/mown every year and (ii) 5 side ditchessmaller ( $<3 \mathrm{~m}$ wide) and shorter ditches connected at either end to a main arterial drainage ditch, but both banks experience maintenance and vegetation management on an annual basis. In addition, a long-term record collected by the Environment Agency of England and Natural England for 3 sites (1989-2014) in the drainage network was available. These data provide a long-term historical perspective of macroinvertebrate biodiversity within the agricultural drainage ditches. The number of taxa recorded from the three sites was calculated within 5 year windows (1989-1993; 1994-1998; 1998-2003 and 2004-2008) except the final period which comprised 6 years (2009-2014). Due to variability in the number of samples within each time period and the sampling technique employed over time only presence/absence data were considered.

\section{Macroinvertebrate sampling}

Aquatic macroinvertebrate taxa were sampled from the margin of each ditch using the sweep-sample technique due to the limited flow velocity and depth in excess of $1.5 \mathrm{~m}$ with a standard pond net (mesh size $1 \mathrm{~mm}$ ) over a three-minute period (García-Criado \& Trigal, 2005). This allowed a representative sample to be obtained whilst also facilitating comparability between sites (Murray-Bligh, 1999). Aquatic macroinvertebrate samples were collected during each survey (spring-April, summer-June and winter-December) from each site. The samples were preserved in the field in $4 \%$ formaldehyde solution and processed into $70 \%$ industrial methylated spirits in the laboratory. The majority of faunal groups were identified to species level; although Sphaeriidae were identified to genus, Diptera and Hydrachnidiae were recorded to family level, and Oligochaeta and Collembola were recorded as such.

\section{Statistical analysis}

Three measures of aquatic macroinvertebrate diversity were calculated: alpha, beta and gamma diversity. Alpha diversity represents the faunal diversity within an individual sample site; beta diversity characterises the spatial/temporal distribution and heterogeneity in community composition between individual sites within a given area, and gamma diversity represents the overall biodiversity across the entire study region (Arellano \& Halffter, 2003; Anderson et al., 2011). Taxon richness and abundance was calculated for each ditch site (alpha) using PRIMER 6 (Clarke \& Gorley, 2006). To achieve this, species-abundance data from individual ditches for each season were pooled. Gamma diversity was calculated by combining species-abundance data from each ditch site. The data were examined to ensure that the data complied with the underlying assumptions of parametric statistical tests (e.g., normal distribution). Where these 
assumptions were not met, abundance data were $\log _{10}$ transformed. Differences in faunal diversity among ditches (main and side) were examined using one-way analysis of variance (ANOVA) in SPSS (version 21, IBM Corporation, New York). In addition, Seasonal differences (nested within ditch type) in macroinvertebrate richness and abundance among the ditch types were examined using a nested analysis of variance (nested ANOVA) with Bonferroni post hoc tests used to determine where significant differences between seasons occurred (van de Meutter et al., 2005).

The heterogeneity of macroinvertebrate communities between main and side ditch sites, and season (spring, summer and winter) samples was assessed using analysis of similarity (ANOSIM) and summarised using non-metric multidimensional scaling (NMDS) ordination plots (using Bray-Curtis dissimilarity metric) in PRIMER v6 (Clarke \& Gorley, 2006). SIMPER analysis was undertaken to determine which taxa contributed most to the seasonal (spring, summer and winter) differences in macroinvertebrate community composition and between site differences (main vs. side ditches) in taxonomic composition. Faunal abundance data were square-root transformed prior to ANOSIM, NMDS and SIMPER analysis.

The conservation value of the aquatic macroinvertebrates within each ditch site was determined using the community conservation index (CCI). This incorporates both rarity of macroinvertebrate species at a national scale in the UK and the community richness (see Chadd \& Extence, 2004 for further methodological details). CCI can provide the basis for the development of conservation strategies when used in conjunction with knowledge of the habitat requirements of target organisms and communities (Chadd \& Extence, 2004).

\section{Results}

Macroinvertebrate biodiversity

A total of 167 taxa were recorded with 148 taxa (mean: 85.6) recorded from the main ditches and 133 taxa recorded from the side ditch sites (mean: 70.8) during the three surveys in 2014 (Table 1; see Supplementary Material for taxa list). The largest numbers of taxa were recorded from the orders Coleoptera (55), Gastropoda (25), Trichoptera (19), Hemiptera (17) and Odonata (13). A total of 32 taxa were unique to the main ditches (1 Gastropoda, 1 Bivalvia, 1 Malocstraca, 1 Arguloidea, 1 Ephemeroptera, 3 Odonata, 3 Hemiptera, 16 Coleoptera, and 5 Trichoptera) and 20 taxa were unique to the side ditches (1 Gastropoda, 1 Hemiptera, 12 Coleoptera, 4 Trichoptera and 2 Diptera). Two non-native taxa, Crangonyx pseudogracilis Bousfield, 1958 (Amphipoda) and Potamopyrgus antipodarum (Gray, 1843) (Gastropoda), were both recorded from all 12 study sites. Both species were abundant; $C$. pseudogracilis accounted for up to $13 \%$ of the sample abundance and $P$. antipodarum accounted for up to $12 \%$ of sample abundance.

Macroinvertebrate taxonomic richness was significantly greater within the main arterial ditches when compared with the side ditches (ANOVA $\left.F_{1,11}=6.738 ; P=0.027\right)$. The greatest number of taxa (96 taxa) was recorded from a main ditch site whilst the lowest diversity (64 taxa) was recorded from two side ditches. Higher taxonomic richness in the main ditches was driven by a greater richness of Hemiptera, Coleoptera and Trichoptera taxa when compared with the side ditches (Fig. 1). No significant difference in aquatic macroinvertebrate abundance among main and side ditches was recorded (ANOVA $F_{1,11}=0.309 ; P=0.590$ ).

When individual seasons (spring, summer and autumn) were considered, a significant difference in the number of taxa (nested ANOVA $F_{4,29}=8.949$; $P<0.001)$ was observed among main and side drainage ditches (Fig. 2a). Post hoc analysis indicated that macroinvertebrate faunal richness was significantly lower during the winter season than the spring or summer season (Fig. 2a). Aquatic Coleoptera (spring $=38$ taxa, summer $=40$ taxa, winter $=17$ taxa; ANOVA $F_{2,35}=19.416 ; P<0.001$ ), Hemiptera (spring $=13$ taxa, summer $=14$ taxa, winter $=9$ taxa; ANOVA $F_{2,35}=10.931 ; P<0.001$ ) and Diptera (spring $=8$ taxa, summer $=9$ taxa, winter $=4 \quad$ taxa; $\quad$ ANOVA $\quad F_{2,35}=5.533$; $P=0.008$ ) taxa displayed a significantly lower richness during the winter season. Aquatic macroinvertebrate abundance did not differ among the three seasons (nested ANOVA $F_{4,29}=0.740 P=0.573$ : Fig. $2 b$ ) or when all seasons were considered (average abundance: 3640 individuals all site; 3604 individuals main ditches; 3690 individuals-side ditches; Table 1).

The number of macroinvertebrates recorded in the historical dataset (1989-2014) was 338 taxa 


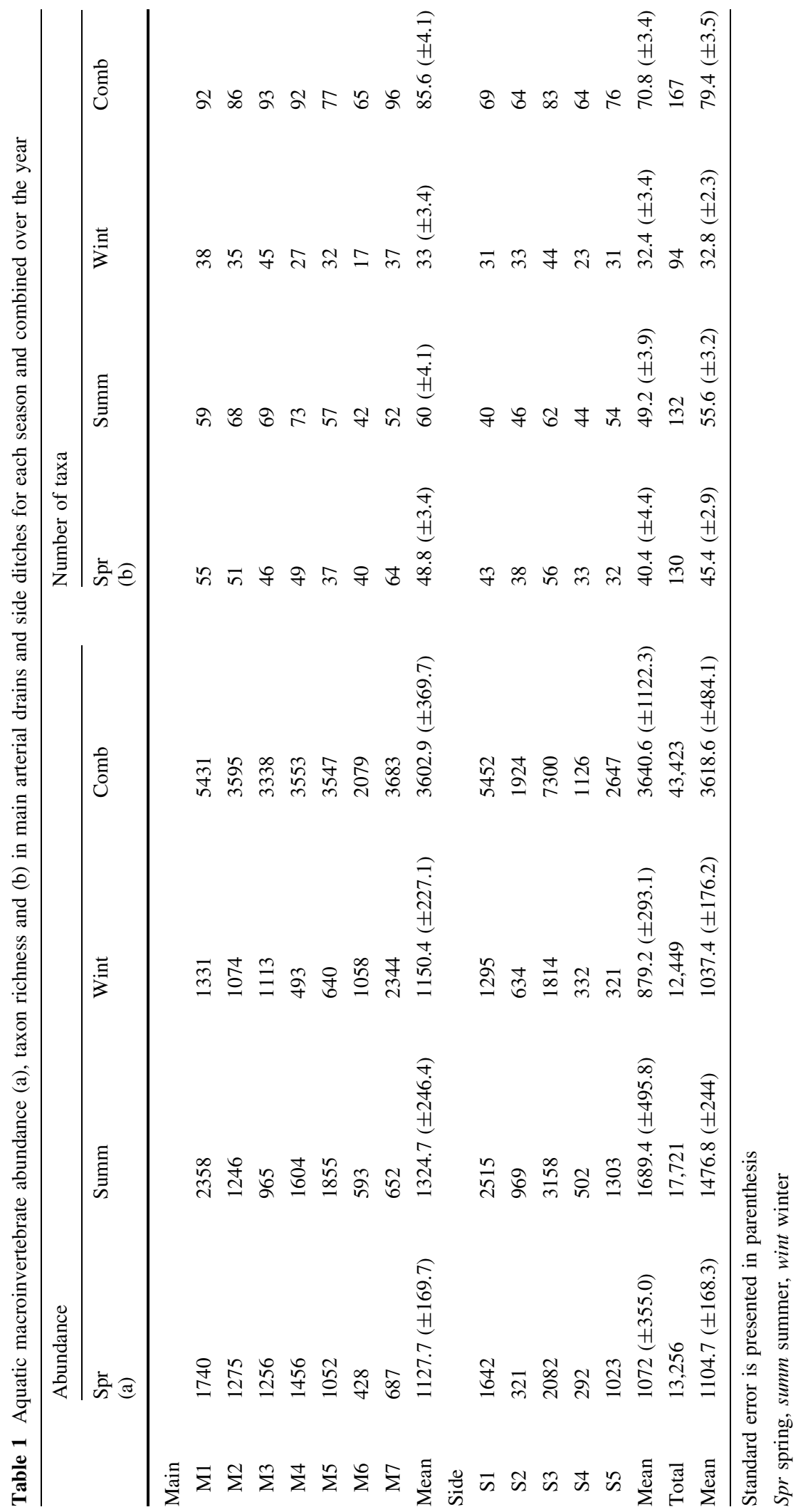


Fig. 1 Total number of taxa within the main macroinvertebrate groups recorded from the 12 sample sites on the North and South Drove of Deeping Fen (Lincolnshire, UK)
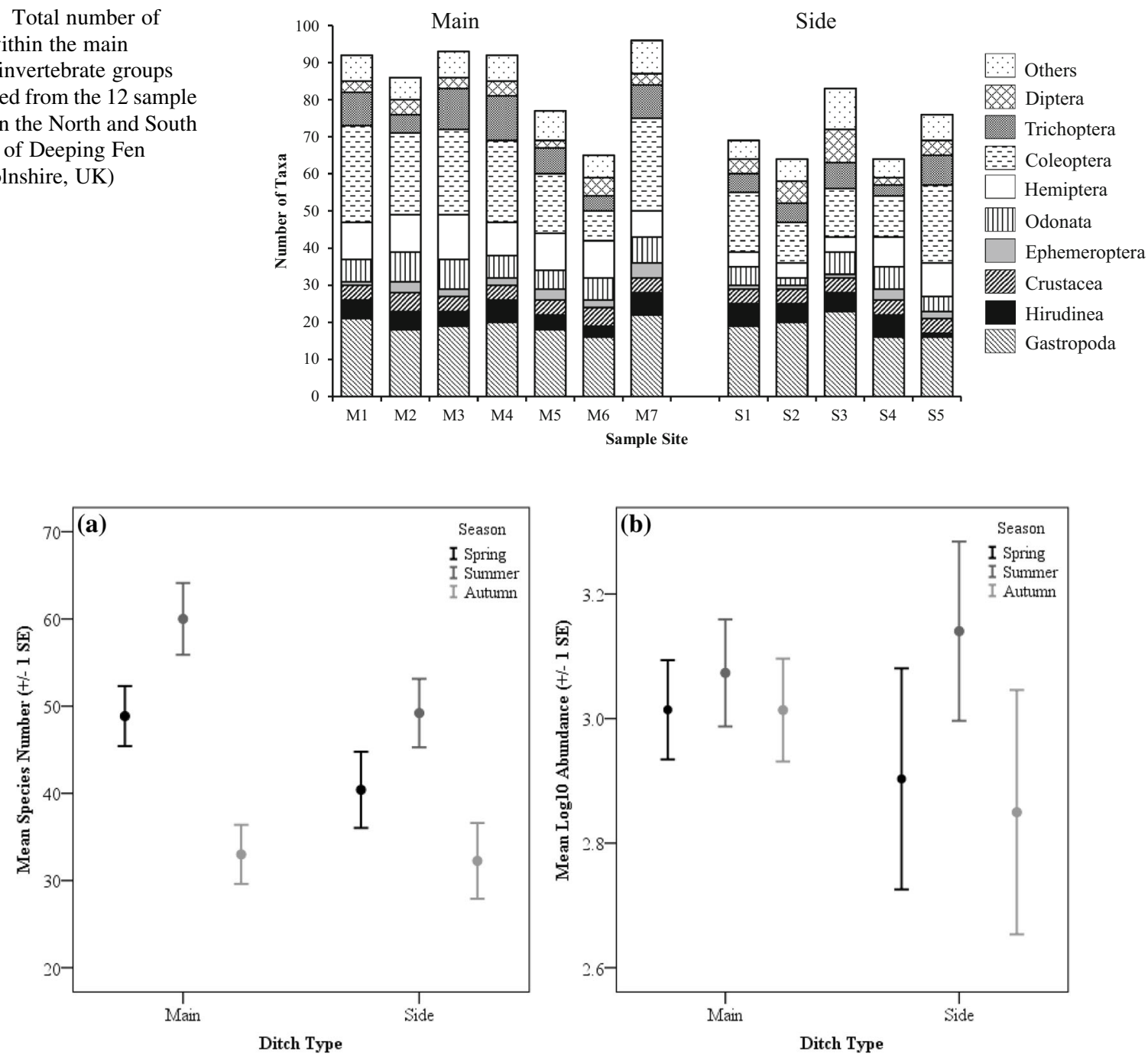

Fig. 2 Error bar graphs indicating (a) Mean taxon richness $( \pm 1$ $\mathrm{SE})$ and (b) mean community abundance ( $\pm 1 \mathrm{SE})$ recorded in the main and side drainage ditches during the spring, summer

(including 131 Coleoptera, 42 Gastropoda/Bivalvia, 31 Hemiptera and 29 Trichoptera). The number of taxa recorded was similar between 1994 and 1998 (187 taxa), 1999-2003 (180 taxa) and 2004-2008 (191 taxa). Faunal richness was lowest for the 1989-1993 (129 taxa) and 2009-2014 time periods (167 taxa).

\section{Community heterogeneity}

A significant difference in community composition was recorded between main and side ditch communities when all sampling dates were considered together (ANOSIM $r=0.753 P=0.01$ ) and resulted in

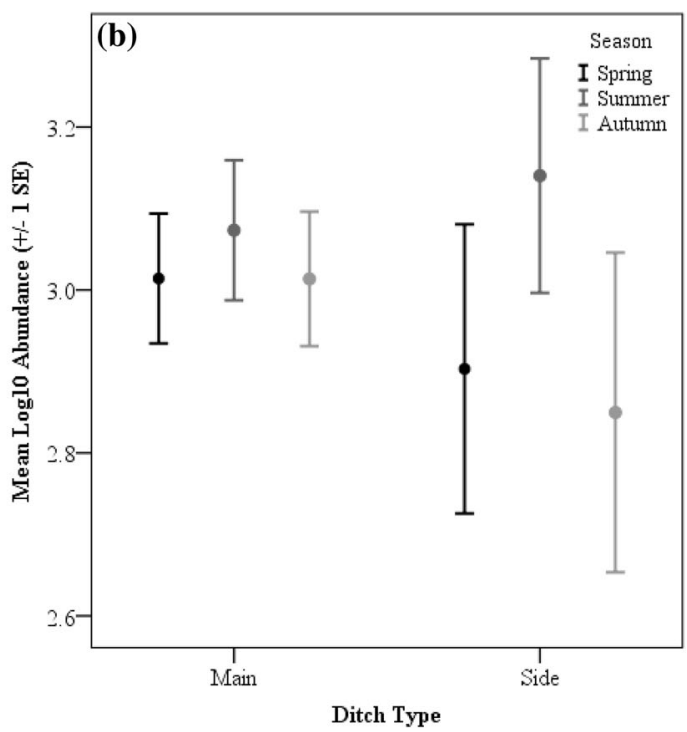

and winter sampling seasons on the North and South Drove of Deeping Fen (Lincolnshire, UK)

separation of main and side ditch samples within the NMDS ordination plots (Fig. 3a). The side ditch sites were more widely dispersed, indicating greater community heterogeneity. SIMPER analysis indicated significant community heterogeneity and that differences between main and side ditches were driven by greater abundances of 2 gastropods (Radix balthica (Linnaeus, 1758) — total abundance main: 69, side: 2178 — contributing $4.25 \%$ to the dissimilarity and Physa fontinalis (Linnaeus, 1758)—total abundance main:75, side: 1450 - contributing $3.63 \%$ to the dissimilarity) in the side ditches and greater abundances of an Ephemeroptera larvae (Cloeon dipterum (Linnaeus, 
Fig. 3 Two-dimensional NMDS plot of dissimilarity (Bray-Curtis) of invertebrate communities within (a) the main and side drainage ditches and (b) seasonal (spring, summer and winter) invertebrate communities within the agricultural drainage ditches of North and South Drove of Deeping Fen (Lincolnshire, UK)
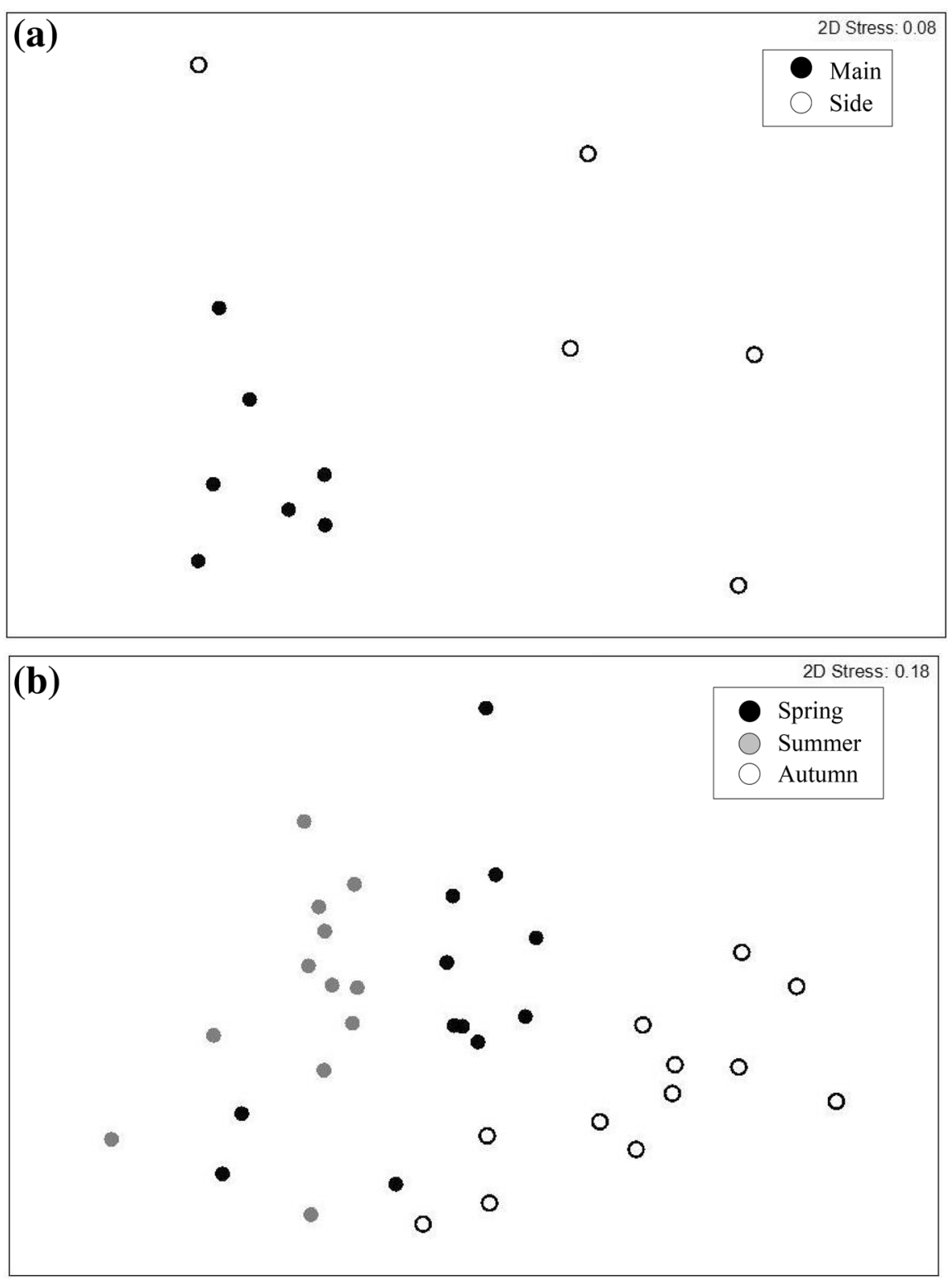

1761) — total abundance main: 5326, side: 412—contributing $6.31 \%$ to the dissimilarity) and an amphipod shrimp (Gammarus pulex (Linnaeus, 1758)—total abundance main: 3483 , side: 285 - contributing $4.82 \%$ to the dissimilarity) in the main ditch sites. When the samples from each season (spring, summer and winter) were examined using NMDS, clear seasonal differences in drainage ditch macroinvertebrate community composition were identified (Fig. 3b). In addition, ANOSIM indicated that there were significant differences between spring, summer and winter macroinvertebrate community composition (ANOSIM $r=0.506, P=0.01$ ).

\section{Conservation value}

Three nationally scarce or nationally notable Coleoptera were identified within the ditch sites; Agabus uliginosus (Linnaeus, 1761) (Dytiscidae) was recorded from a single side ditch; Oulimnius major (Rey, 1889) (Elmidae) was recorded within both main ditches; and Scarodytes halensis (Fabricius, 1787) (Dytiscidae) was recorded from one main and side ditch site. In addition, Agabus undulatus (Schrank, 1776) (Dytiscidae), listed as Lower Risk-Near Threatened on the IUCN red data list 2001, was recorded 
Table 2 Macroinvertebrate community conservation index (CCI) scores from the 12 sample sites for individual seasons and all seasons (Total), (0-5 low conservation value; $>5-10$ moderate conservation value; $>10-15$ fairly high conservation value; $>15-20$ high conservation value and $>20$ very high conservation value)

\begin{tabular}{rrrrr}
\hline & Spring & Summer & Winter & Total \\
\hline Main & & & & \\
M1 & 9 & 9 & 9 & 10 \\
M2 & $\mathbf{1 2}$ & $\mathbf{1 3}$ & 8 & $\mathbf{1 4}$ \\
M3 & $\mathbf{1 9}$ & $\mathbf{1 5}$ & 9 & $\mathbf{2 2}$ \\
M4 & 9 & 9 & 8 & 10 \\
M5 & 8 & 9 & 9 & 9 \\
M6 & 9 & 8 & 8 & 9 \\
M7 & 9 & 8 & 9 & 9 \\
Side & & & & \\
S1 & $\mathbf{1 3}$ & 9 & 7 & $\mathbf{1 4}$ \\
S2 & 8 & 8 & 7 & 9 \\
S3 & 8 & 8 & 8 & 8 \\
S4 & 9 & 10 & 9 & 10 \\
S5 & $\mathbf{2 2}$ & 9 & $\mathbf{2 0}$ \\
\hline
\end{tabular}

Fairly high, high and very high conservation value scores are presented in bold

from a single side ditch. Based on the CCI scores derived, the macroinvertebrate communities within two ditch sites were of fairly high conservation value (1 main and 1 side ditch); one side ditch was of a high conservation value and a single main drainage ditch was of a very high conservation value (Table 2). No ditches were recorded to have a low conservation value. There was no significant differences in CCI scores between main and side ditches for any season or for the combined dataset (ANOVA $F_{1,11}=0.003$ $P=0.960)$. In addition, no significant difference in conservation value between the seasons was recorded (Spring: ANOVA $F_{1,11}=0.208 P=0.658$, Summer: ANOVA $F_{1,11}=1.104 P=0.318$, Autumn ANOVA $\left.F_{1,11}=0.473 P=0.507\right)$.

\section{Discussion}

Macroinvertebrate biodiversity and community heterogeneity

This study sought to characterise the aquatic macroinvertebrate biodiversity and conservation value of lowland agricultural drainage ditches. The results of the study illustrate that the drainage ditches support high biodiversity at both the individual site (alpha diversity) and landscape scale (gamma diversity), and that there was significant between site heterogeneity (beta diversity). The number of aquatic macroinvertebrate taxa recorded in this study (167 taxa) was markedly higher than that recorded during other studies of drainage ditches in the UK (Davies et al., 2008b), despite the limited number of samples, and is comparable to other wetland habitats (Williams et al., 2003). When the long-term historical data (1989-2014) available for the sites were included with those recorded during the current study, the number of taxa almost doubled to 338 taxa. This figure is markedly higher than any other study reported in the UK and second highest among drainage ditch studies of macroinvertebrate biodiversity reported internationally (Table 3). However, this figure is an underestimate as dipteran larvae were only resolved to family level in this study.

The high biodiversity recorded may reflect the high connectivity within the drainage network (River Welland and the River Glen) and proximity to remnant fen wetlands (Baston Fen SSSI and Thurlby Fen Nature reserve) and fen restoration projects (Willow Tree Fen nature reserve). Traditional wetland fens in the UK typically support exceptionally high aquatic macroinvertebrate diversity (e.g., $>30$ taxa with a conservation designation were recorded from 19 wetland fen waterbodies (Painter, 1999) and 137 species of Coleoptera were recorded from 157 fen ditch samples (Eyre et al., 1990; Foster et al., 1990). The drainage ditches may effectively function as aquatic corridors through the agricultural landscape, linking natural, semi-natural and artificial habitats (Mazerolle, 2004; Buisson et al., 2008). We assumed that due to more frequent management operations (water level change, dredging, bank cutting), main arterial drainage ditches would support lower macroinvertebrate biodiversity and conservation value than the less frequently managed side ditches. No evidence was found to support this assumption since the side ditches supported significantly lower aquatic macroinvertebrate taxon richness (alpha) than main drainage ditch sites. The management practices, primarily designed to maintain the hydrological functioning (conveyance of water) may actually inadvertently promote and enhance aquatic macroinvertebrate diversity. Ditch cleaning 
Table 3 The number of macroinvertebrate taxa recorded in other published studies which have examined the biodiversity or wider conservation value of artificial drainage channels and ditches

\begin{tabular}{|c|c|c|c|c|}
\hline Source & Location & Number sites & $\begin{array}{l}\text { Number } \\
\text { of taxa }\end{array}$ & Study date and duration \\
\hline $\begin{array}{l}\text { Armitage et al. } \\
\text { (2003) }\end{array}$ & River Frome floodplain, Dorset, UK & $\begin{array}{l}1 \text { ditch, } 16 \\
\text { sites }\end{array}$ & 145 & 1 year $(1998)$ \\
\hline $\begin{array}{l}\text { Clare and Edwards } \\
\text { (1983) }\end{array}$ & $\begin{array}{l}\text { Gwent Levels, River Severn Estuary, Wales, } \\
\text { UK }\end{array}$ & 60 sites & $58^{\mathrm{a}}$ & 1 year, 6 surveys (1976) \\
\hline $\begin{array}{l}\text { Davies et al. } \\
\quad(2008 \mathrm{a})\end{array}$ & Gloucestershire, Oxfordshire \& Wiltshire, UK & $\begin{array}{l}20 \text { sites/ } \\
\text { ditches }\end{array}$ & 120 & 3 years $(2000,2002$ and 2003) \\
\hline \multirow{2}{*}{$\begin{array}{l}\text { Davies et al. } \\
(2008 b)\end{array}$} & River Cole, Coleshill, Oxfordshire, UK & 11 sites & 120 & 2 years $(2000-2001)$ \\
\hline & Whitchurch, Cheshire, UK & 13 sites & 75 & 2 years $(1997-1998)$ \\
\hline $\begin{array}{l}\text { Hill et al. (this } \\
\text { study) }\end{array}$ & $\begin{array}{l}\text { Deeping Fen, between River Glen and River } \\
\text { Welland }\end{array}$ & $\begin{array}{c}12 \text { sites } / 9 \\
\text { ditches }\end{array}$ & $167^{\mathrm{b}}$ & 1 year, 3 surveys (2014) \\
\hline Historic data & Lincolnshire, UK & 3 Sites & $338^{2}$ & $1989-2014$ \\
\hline $\begin{array}{l}\text { Langheinrich et al. } \\
\text { (2004) }\end{array}$ & Drömling, Saxony, Germany & $\begin{array}{l}11 \text { sites/ } \\
\text { channels }\end{array}$ & 227 & $\begin{array}{l}3 \text { years, } 5 \text { surveys }(1996,1998 \\
\text { and } 2000)\end{array}$ \\
\hline Leslie et al. (2012) & Chesapeake Bay, Maryland, USA & $\begin{array}{l}29 \text { sites/ } \\
\text { ditches }\end{array}$ & 85 & $\begin{array}{l}2 \text { months (February-March } \\
\text { 2008) }\end{array}$ \\
\hline Painter (1999) & Wicken Fen, Cambridgeshire, UK & $\begin{array}{l}17 \text { sites/ } \\
\text { channels }\end{array}$ & $109^{\mathrm{c}}$ & 1 month (June 1994) \\
\hline $\begin{array}{l}\text { Simon and Travis } \\
\text { (2011) }\end{array}$ & Tates Hell State Forest, Florida, USA & 6 sites/ditches & 42 & 3 surveys (June-August 2009) \\
\hline $\begin{array}{l}\text { Verdonschot et al. } \\
\text { (2011) }\end{array}$ & Central Netherlands & $\begin{array}{l}9 \text { sites/ } \\
\text { drainage } \\
\text { ditches }\end{array}$ & 226 & 2 months (June-July 2005) \\
\hline $\begin{array}{l}\text { Verdonschot and } \\
\text { Higler (1989) }\end{array}$ & $\begin{array}{l}\text { Overijssel province, Drenthe provinde and } \\
\text { Demmerik polder, Netherlands }\end{array}$ & 150 sites & $360^{\mathrm{d}}$ & $\begin{array}{l}\text { Composite study of research in } \\
1970 \text { s and } 1980 \text { s }\end{array}$ \\
\hline $\begin{array}{l}\text { Whatley et al. } \\
\text { (2014a) }\end{array}$ & $\begin{array}{l}\text { Hoogheemraadschap, North Holland, } \\
\text { Netherlands }\end{array}$ & 29 sites & 71 & 1985-2007 \\
\hline $\begin{array}{l}\text { Whatley et al. } \\
\text { (2014b) }\end{array}$ & $\begin{array}{l}\text { Wormer, Jisperveld and Naardermeer, North } \\
\text { Holland, Netherlands }\end{array}$ & $\begin{array}{l}6 \text { sites/ } \\
\text { channels }\end{array}$ & $70^{\mathrm{e}}$ & $\begin{array}{l}2 \text { months (August-September } \\
\text { 2011) }\end{array}$ \\
\hline $\begin{array}{l}\text { Whatley et al. } \\
(2015)\end{array}$ & North Holland, Netherlands & $\begin{array}{l}84 \text { sites/ } \\
\text { channels }\end{array}$ & 159 & 4 years $(2008-2011)$ \\
\hline $\begin{array}{l}\text { Williams et al. } \\
\text { (2003) }\end{array}$ & River Cole, Coleshill, Oxfordshire, UK & $\begin{array}{l}20 \text { sites/ } \\
\text { channels }\end{array}$ & 90 & 1 year-2000 \\
\hline
\end{tabular}

For each source the geographical location, number of ditches and sites examined, the number of macroinvertebrate taxa and duration of the study is included to provide comparison with the results of the current study and historic sampling on Deeping Fen

${ }^{\text {a }}$ Clare \& Edwards (1983) report 58 taxa in a reduced dataset

b Diptera larvae resolved to family level only

c Painter (1999) Only Coleoptera, Mollusca and Odonata reported

d Verdonschot and Higler (1989) the figure indicated comprises those selected for inclusion in analysis

e Whatley et al. (2014b) only insect taxa reported

and dredging has been shown to positively influence Trichoptera presence in ditches (Twisk et al., 2000), and dredging can remove nutrient-rich sediment (Whatley et al., 2014a) and reset ditch habitats to an earlier successional stages (Clarke, 2015). The rotational management of sites over time means a variety of vegetation successional stages will be present across the sites and collectively these provide a wide range of habitats suitable for macroinvertebrates (Painter et al., 1999; Clarke, 2015).

Significant spatial and temporal aquatic macroinvertebrate community heterogeneity was recorded 
between the main and side drainage ditches. The primary differences in the communities reflect the presence of taxa associated with slow flow and lotic conditions, such as the Crustacea G. pulex, in the main arterial drains compared to the side ditches, which supported much higher abundances of gastropods such as $P$. fontinalis and $R$. balthica. The ponding of water in side ditches during the winter and abundance of structurally complex macrophyte communities within them provide ideal habitats and conditions for gastropods (Brönmark, 1985; Hinojosa-Garro et al., 2010). However, invertebrate communities among side ditches were more heterogeneous than the main drainage ditches; side ditches being more widely dispersed in the NMDS. This may reflect the wider range of successional stages present across side ditches (from freshly managed to large vegetation coverage) when compared to the main arterial ditches where one bank was always vegetated. The high seasonal heterogeneity recorded in this study reflects life-cycle variability associated with seasonal changes in aquatic macroinvertebrate communities typical of most freshwater systems.

Conservation value and management of the resource

While this study and others have illustrated the importance of ditches for biodiversity conservation in agricultural areas (e.g., Armitage et al., 2003; Williams et al., 2003; Davies et al., 2008b; Clarke, 2015), in many regions it currently relies on designated protected areas (e.g., nature reserves) (Twisk et al., 2000; Mainstone, 2008; McDonald et al., 2008). Protected area legislation, at a national and European scale largely concentrates on the identification and selection of the best examples of natural or seminatural habitats. However, agricultural activities and urban expansion are projected to threaten the flora and fauna within many of these protected areas (Guneralp $\&$ Seto, 2013) and it is increasingly recognised that the long-term conservation of habitats and species requires new/novel approaches.

In many areas, there have been calls and incentives for de-intensification of agricultural land to reverse the decline in biodiversity through the use of voluntary agri-environment schemes (Davies et al., 2008a). These schemes in the UK aim to reduce the widespread pollution of aquatic systems in agricultural landscapes typically through the development of buffer strips. However, while this may be an option in low productivity agriculture and on land of marginal agricultural value, in highly productive and agricultural intensive landscapes this is not a realistic or economically viable option. In addition, it may be more difficult to legitimise and implement when the waterbodies in question are designated as artificial or heavily modified waterbodies (AWB or HMWB) under the EU Water Framework Directive and little pre-existing information regarding their ecological value is available.

The use of management strategies to increase the physical diversity of anthropogenic habitats has begun to be used in some aquatic systems as a means to support native flora and fauna (therefore promoting and enhancing biodiversity) whilst not reducing the effectiveness of their primary anthropogenic function (Moyle, 2014). The management and conservation of agricultural drainage ditches represent a prime example of a location where the principles of 'reconciliation ecology' (sensu Rosenzweig, 2003) could be applied for the mutual benefit of societal requirements and conservation of natural resources. Reconciliation ecology acknowledges that humans increasingly dominate many ecosystems, especially agricultural landscapes (Rosenzweig, 2003), and that society has a responsibility to determine what it wants these systems to look like aesthetically, how they function and what target species we want them to support. It proposes that in many instances relatively small modifications to management (e.g., cut bank sides on alternate years) can promote aquatic alpha and gamma diversity and conservation value in agricultural landscapes (Twisk et al., 2000) whilst not reducing the anthropogenic utility of ditches. Ditches are well suited to reconciliation ecology and many already support significant taxonomic richness (Armitage et al., 2003; Verdonschot et al., 2011). Given there will be no loss of agricultural land or change to the primary function of the ditches (irrigation and flood risk management), only very minor changes to existing management strategies and no/very low financial costs, land managers and farmers may be more willing to implement reconciliation ecology approaches to protect or enhance biodiversity than agri-environment schemes. If more widely accepted and adopted, reconciliation ecology could provide a framework for supporting future conservation of biota within 
habitats that are increasingly anthropogenically modified or dominated (Rosenzweig, 2003; Chester \& Robson, 2013).

In the absence of formal legislative protection (the Water Framework Directive and Habitats Directive overlook ditches), the ecology of large networks of agricultural drainage ditches are currently unknown, ignored and potentially under threat. In some intensively farmed landscapes, drainage ditches are being increasingly replaced by sub-surface drainage pipes to increase crop yield (Herzon \& Helenius, 2008). Land managers, farmers, environmental regulators and policy makers need to recognise the conservation value and biological importance of drainage ditches as one of the last remaining aquatic habitats and refuges available in agricultural areas and, where appropriate, provide protection for most valuable sites.

Acknowledgments The authors would like to thank Welland and Deepings Internal Drainage Board for their permission to access sites. The authors would also like to thank Malcolm Doubleday for his guidance around the fen during site selection. We would like to thank Prof Beat Oertli and two anonymous reviewers for their helpful and constructive comments which have significantly improved the manuscript. PJW acknowledges the support of a Loughborough University, School of Social, Political and Geographical Sciences research grant to support the research presented in this paper.

Open Access This article is distributed under the terms of the Creative Commons Attribution 4.0 International License (http:// creativecommons.org/licenses/by/4.0/), which permits unrestricted use, distribution, and reproduction in any medium, provided you give appropriate credit to the original author(s) and the source, provide a link to the Creative Commons license, and indicate if changes were made.

\section{References}

Anderson, M. J., T. O. Crist, J. M. Chase, M. Vellend, B. D. Inouye, A. L. Freestone, N. J. Sanders, H. V. Cornell, L. S. Comita, K. F. Davies, S. P. Harrison, N. J. R. Kraft, J. C. Stegen \& N. G. Swenson, 2011. Navigating the multiple meanings of $\beta$ diversity: a road map for the practicing ecologist. Ecology Letters 14: 19-28.

Armitage, P. D., K. Szoszkiewicz, J. H. Blackburn \& I. Nesbitt, 2003. Ditch communities: a major contributor to floodplain diversity. Aquatic Conservation: Marine and Freshwater Ecosystems 13: 165-185.

Arellano, L. \& G. Halffter, 2003. Gamma diversity: derived from and a determinant of alpha diversity and beta diversity. An analysis of three tropical landscapes. Acta Zoologica Mexicana 90: 27-76.

Boyes, J. \& R. Russell, 1977. The Canals of Eastern England. David and Charles, Newton Abbot.
Brönmark, C., 1985. Freshwater snail diversity: effects of pond area, habitat heterogeneity and isolation. Oecologia 67: 127-131.

Buisson, R. S. K., P. M. Wade, R. L. Cathcart, S. M. Hemmings, C. J. Manning \& L. Mayer, 2008. The Drainage Channel Biodiversity Manual: Integrating Wildlife and Flood Risk Management. Association of Drainage Authorities and Natural England, Peterborough.

Chadd, R. \& C. Extence, 2004. The conservation of freshwater macroinvertebrate populations: a community based classification scheme. Aquatic Conservation: Marine and Freshwater Ecosystems 14: 597-624.

Chester, E. T. \& B. J. Robson, 2013. Anthropogenic refuges for freshwater biodiversity: their ecological characteristics and management. Biological Conservation 166: 64-75.

Clare, P. \& R. W. Edwards, 1983. The macroinvertebrate fauna of the drainage channels of the Gwent Levels, South Wales. Freshwater Biology 13: 205-225.

Clarke, K. R. \& R. N. Gorley, 2006. PRIMER v6: User Manual/ Tutorial. PRIMER E-Ltd, Plymouth.

Clarke, S. J., 2015. Conserving freshwater biodiversity: the value, status and management of high quality ditch systems. Journal for Nature Conservation 24: 93-100.

Davies, B. R., J. Biggs, P. J. Williams, T. J. Lee \& S. Thompson, 2008a. A comparison of the catchment sizes of rivers, streams, ponds, ditches and lakes: implications for protecting aquatic biodiversity in an agricultural landscape. Hydrobiologia 597: 7-17.

Davies, B., J. Biggs, P. Williams, M. Whitfield, P. Nicolet, D. Sear, S. Bray \& S. Maund, 2008b. Comparative biodiversity of aquatic habitats in the European agricultural landscape. Agriculture. Ecosystems and Environment 125: 1-8.

EU, 2000. Directive 2000/60/EC of the European Parliament and of the Council of 23 October 2000 establishing a framework for Community action in the field of water policy, 22/12/2000. Official Journal 327: 1-73.

Environment Agency, 2009. River Basin Management Plan, Anglian River Basin District Annex I: Designating Artificial \& Heavily Modified Water Bodies. Environment Agency, UK.

Eyre, M. D., G. N. Foster \& A. P. Foster, 1990. Factors affecting the distribution of water beetle species assemblages in drains of eastern England. Journal of Applied Ecology 109: 217-225.

Foster, G. N., A. P. Foster, M. D. Eyre \& D. T. Bilton, 1990. Classification of water beetle assemblages in arable fenland and ranking of sites in relation to conservation value. Freshwater Biology 22: 343-354.

García-Criado, F. \& C. Trigal, 2005. Comparison of several techniques for sampling macroinvertebrates in different habitats of a north Iberian pond. Hydrobiologia 545: 103-115.

Goulder, R., 2008. Conservation of aquatic plants in artificial watercourses: are drains a substitute for vulnerable navigation canals? Aquatic Conservation: Marine and Freshwater Ecosystems 18: 163-174.

Guneralp, B. \& K. C. Seto, 2013. Futures of global urban expansion: uncertainties and implications of biodiversity conservation. Environmental Research Letters 8: 1-10.

Herzon, I. \& J. Helenius, 2008. Agricultural drainage ditches, their biological importance and functioning. Biological Conservation 141: 1171-1183. 
Hinojosa-Garro, D., C. F. Mason \& G. J. C. Underwood, 2010. Influence of macrophyte spatial architecture on periphyton and macroinvertebrate community structure in shallow waterbodies under contrasting land management. Fundamental and Applied Limnology 177: 19-37.

Katano, O., K. Hosoya, K. Iguchi, M. Yamaguchi, Y. Aonuma \& S. Kitano, 2003. Species diversity and abundance of freshwater fishes in irrigation ditches around rice fields. Environmental Biology of Fishes 66: 107-121.

Langheinrich, U., S. Tischew, R. M. Gersberg \& V. Lüderitz, 2004. Ditches and canals in management of fens: opportunity or risk? A case study in the Drömling Natural Park, Germany. Wetland Ecology and Management 12: 429-445.

Leslie, A. W., R. F. Smith, D. E. Ruppert, K. Bejleri, J. M. McGrath, B. A. Needelman \& W. O. Lamp, 2012. Environmental factors structuring benthic macroinvertebrate communities of agricultural ditches in Maryland. Environmental Entomology 41: 802-812.

Mainstone, C. P., 2008. The role of specially designated wildlife sites in freshwater conservation-an English perspective. Freshwater Reviews 1: 89-98.

Maltby, E. \& M. C. Acreman, 2001. Ecosystem services of wetlands: pathfinder for a new paradigm. Hydrological Sciences Journal 56: 1341-1359.

Maltchik, L., A. Silvia Rolon, C. Stenert, I. Farina Machado \& O. Rocha, 2011. Can rice field channels contribute to biodiversity conservation in Southern Brazilian wetlands? Revista de Biología Tropical 59: 1895-1914.

Mazerolle, M. J., 2004. Drainage ditches facilitate frog movements in a hostile landscape. Landscape Ecology 20: 579-590.

McDonald, R. I., P. Kareiva \& R. T. T. Forman, 2008. The implications of current and future urbanization for global protected areas and biodiversity conservation. Biological Conservation 141: 1695-1703.

Moyle, P. B., 2014. Novel aquatic ecosystems: the new reality for streams in California and other Mediterranean climate regions. River Research and Applications 30: 1335-1344.

Murray-Bligh, J., 1999. Procedures for Collecting and Analysing Macroinvertebrate Samples-BT001. The Environment Agency, Bristol.

Natural England, 2015. SSSI citation for Cross Drain. http:// www.sssi.naturalengland.org.uk/citation/citation_photo/ 1003003.pdf Accessed 31 July 15.

Painter, D., 1999. Macroinvertebrate distributions and the conservation value of aquatic Coleoptera, Mollusca and Odonata in the ditches of traditionally managed and grazing fen at Wicken Fen, UK. Journal of Applied Ecology 36: 33-48.

Rosenzweig, M. L., 2003. Reconciliation ecology and the future of species diversity. Oryx 37: 194-205.
Sayer, C., K. Andrews, E. Shiland, N. Edmonds, R. EdmondsBrown, I. Patmore, D. Emson \& J. Axmacher, 2012. The role of pond management for biodiversity conservation in an agricultural landscape. Aquatic Conservation: Marine and Freshwater Ecosystems 22: 626-638.

Simon, T. N. \& J. Travis, 2011. The contribution of man-made ditches to the regional stream biodiversity of the new river watershed in the Florida panhandle. Hydrobiologia 661: 163-177.

Twisk, W., M. A. W. Noordervliet \& W. J. ter Keurs, 2000. Effects of ditch management on caddisfly, dragonfly and amphibian larvae in intensively farmed peat areas. Aquatic Ecology 34: 397-411.

van de Meutter, F., R. Stoks \& L. De Meester, 2005. The effect of turbidity state and microhabitat on macroinvertebrate assemblages: a pilot study of six shallow lakes. Hydrobiologia 542: 379-390.

van Eerden, M., G. Lenselink \& M. Zijlstra, 2010. Long term changes in wetland area and composition in the Netherlands affecting the carrying capacity for wintering waterbirds. Ardea 98: 265-282.

Verdonschot, P. F. M. \& L. W. G. Higler, 1989. Macroinvertebrates in Dutch ditches: a typological characterization and the status of the Demmerik ditches. Hydrobiological Bulletin 21: 135-142.

Verdonschot, R. C. M., H. E. Keizer-Vlek \& P. F. M. Verdonschot, 2011. Biodiversity value of agricultural drainage ditches: a comparative analysis of the aquatic invertebrate fauna of ditch and small lakes. Aquatic Conservation: Marine and Freshwater Ecosystems 21: 715-727.

Vaikre, M., L. Remm \& E. Rannap, 2015. Macroinvertebrates in woodland pools and ditches and their response to artificial drainage in Estonia. Hydrobiologia 762: 157-168.

Wet Fens Partnership, 2015. The restoration of fenland for people and wildlife. Environment Agency, Peterborough.

Whatley, M. H., E. E. van Loon, H. van Dam, J. A. Vonk, H. G. van der Geest \& W. Admiraal, 2014a. Macrophyte loss drives decadal change in benthic invertebrates in peatland drainage ditches. Freshwater Biology 59: 114-126.

Whatley, M. H., E. E. van Loon, J. A. Vonk, H. G. van der Geest $\&$ W. Admiraal, 2014b. The role of emergent vegetation in structuring aquatic insect communities in peatland drainage ditches. Aquatic Ecology 48: 267-283.

Whatley, M. H., J. A. Vonk, H. G. van der Geest \& W. Admiraal, 2015. Temporal abiotic variability structures invertebrate communities in agricultural drainage ditches. Limnologica 52: 20-29. doi:10.1016/j.limno.2015.03.001

Williams, P., M. Whitfield, J. Biggs, S. Bray, G. Fox, P. Nicolet \& D. Sear, 2003. Comparative biodiversity of rivers, streams, ditches and ponds in an agricultural landscape in Southern England. Biological Conservation 115: 329-341. 